Cuadernos de Historia Contemporánea

ISSN: 0214-400X

http://dx.doi.org/10.5209/CHCO.56277

\title{
Class, Space and Urban Development: Madrid 1860-1936
}

Inbal Ofer ${ }^{1}$

Santiago de Miguel Salanova: Madrid, Sinfonía de una Metrópoli Europea 18601936, Madrid, Los Libros de La Catarata, 2016. 288 pp.

Luis Díaz Simón: Los Barrios Bajos de Madrid 1880-1936, Madrid, Catarata, 2016. $272 \mathrm{pp}$.

José $\mathrm{M}^{\mathrm{a}}$ Beascoechea Gangoiti \& Luis Enrique Otero Carvajal (eds.): Las Clases Medias Urbanas. Transformación y Cambio Social and España, 1900-1936, Madrid, Los Libros de La Catarata, 2015. 272 pp.

The three books under review in this section constitute part of the work of a research group titled Space, Society and Culture in the Contemporary Age (Espacio, Sociedad y Cultura en la Edad contemporánea) which formed at the Complutense University of Madrid in 2006. The group, directed by Luis Enrique Otero Carvajal and Gutmaro Gómez Bravo, focuses on the history of the Spanish capital and its metropolitan area from demographic, economic, social, political and scientific perspectives. The reviewed books span the years 1860-1936: a period in which the Spanish capital made its progressive transformation into a modern metropolis. Together they explore a variety of social, technological and demographic developments that stood at the heart of the massive urbanization and modernization processes undergone by Spanish society during the years of the Restoration and the Second Republic.

The two monographs by Santiago de Miguel Salanova and Luis Díaz Simón confront these changes from a highly localized perspective. The first monograph explores the development of the capital's center from the approval of the urban reform plan of the Puerta del Sol (1862) and through the construction of the Gran Vía (19101936). The second monograph focuses on the "lower" neighborhoods to the south of the capital's center where the majority of Madrid's working class population concentrated in the years prior to the development of the Madrid's southern Extension. Both monographs draw on a variety of historical sources such as reports by the local press; the different urban development and construction plans that were debated and implemented in the capital; as well as on the Municipal Census of Inhabitants of the City of Madrid for the years 1860, 1880, 1905 and 1930. They complement several

1 Department of History, Philosophy and Judaic Studies. The Open University of Israel (Israel)

E-mail: inbalof@openu.ac.il 
other works published in the past decade by Borja Carballo Barral, Fernando Vicente Albarrán, Rubén Pallol Trigueros, Nuria Rodríguez Martín and others, which focus on the history of Madrid from the approval of the Extension or Castro Plan (1860) and up to the irruption of the Civil War.

Santiago de Miguel Salanova's book starts off by examining the debates surrounding the approval of the Castro Plan and the Urban Reform Plan of the Puerta del Sol. He situates the two plans against the political background and the context of everyday life in the capital during the second half of the $19^{\text {th }}$ century. The revolutionary events that took place in Madrid during the summer of 1854 exposed the difficulty of moving troops and ammunitions in case of emergency. The outbreaks of Typhoid (1885) and of Cholera (1891) accentuated the existing preoccupations of politicians and of health experts regarding the unsanitary housing conditions that reigned in the capital and the lack of sufficient potable water. These conditions led in the view of many to Madrid's high death toll (28 out of 1,000 persons in 1905, in comparison to between 15 and 20 deaths per 1,000 persons in other Western European capitals) which earned it the nickname City of Death (ciudad de la muerte).

The first chapter in the book analyzes in great detail the social and economic costs of urban reform: the expropriation of privet homes and businesses, the processes of demolition and the prolonged process of re-construction. The author examines the 1836 Law of Expropriation (which provided the municipal authorities with a legal framework for seizing private property) as well as reactions of the community affected by these measures. Using the Municipal Census of Inhabitants he zooms-in on specific zones and streets, thus offering a micro-history of the process of urban reform and expansion as it was experienced by individuals and households belonging to different socio-economic backgrounds.

Relying on the Municipal Census the second chapter analyses the class makeup of the old city-center, the ways in which its inhabitants used private and public space and the nature of social segregation within this zone. As the author rightly notes during the first half of the $19^{\text {th }}$ century social segregation within Madrid's city-center was mostly vertical by nature. This meant that households of a different socio-economic standing often inhabited the same streets, and even the same houses. While the more affluent households occupied the lower floors and bigger apartments the poorer households occupied single rooms and shared apartments in the higher floors. Despite the poor living conditions of servants and of other low-income populations the quality of infrastructure was better in this zone and the phenomenon of "infraviviendas" (that is, makeshift houses that were not suited for their inhabitants' most basic living requirements) was not as pronounced as it was in the lower neighborhoods. All across the city, however, the housing market was characterized by constant mobility due to the pronounced reliance of all classes on the practice of leasing rather than owning property.

Chapters $3 \& 4$ explore the phenomenon of internal migration during the second half of the $19^{\text {th }}$ century and its effects on the capital's economy and labor market. The author analyses the decrease in the number of qualified laborers and of craftsmen amongst the inhabitants of the capital and the increased demand for unqualified laborers, especially in the field of construction. He then moves on to examine the ways in which the consolidation of Madrid as a financial hub led to an increased demand for service employees and of liberal professionals.

Chapters $5 \& 6$ make the transition into the $20^{\text {th }}$ century by examining the spatial and social implications of the construction of the Gran Via, as well as the consoli- 
dation of a stricter concept of zoning throughout the capital. As the $20^{\text {th }}$ century progressed social segregation throughout Madrid became more horizontal in nature. The center of Madrid acquired increased administrative and financial functions while the northern suburbs absorbed the growing middle classes. During the same period the rising land prices drove Madrid's working classes and the growing migrant population into the newly constructed Southern Extension and the suburbs of the capital's outer parameter.

Chapters $7 \& 8$ analyze the profile of internal migration and of urban expansion following the First World War. By 1930 migrants made up 57\% of the capital's population, of special prominence were those arriving from Asturias, Castilla la Mancha and Andalusia. Chapter 7 analyzes the role of geographically based social networks in providing migrants with a sense of belonging (through the joint commemoration of local festivals, the maintenance of cultural and culinary traditions etc') and in enabling them to secure housing and work in the capital. The final chapter explores the changes which took place in the physiognomy of the city following the installation of telephone and metro lines; the construction of the Ciudad Universitaria; the opening of large-scale department stores such as El Corte Inglés; and the consolidation of Madrid's city between the Plaza de Cibeles and the Puerta del Sol. It then looks at the diversification of the capital's labor market with the expansion of the service industry and the increased entry of women into that sector.

Luis Díaz Simón's book focuses on the south-eastern or "lower" neighborhoods of Madrid's city-center such as Arganzuela and La Latina. The author starts off by examining the material realities of everyday life in those neighborhoods: the crowdedness, lack of clean water, apartments lacking in light and in fresh air and the low quality of nutrition. The first chapter in the book documents the outbreaks of cholera (1885) typhoid (1891) in the capital; the spread of diseases in spatial terms; and their toll on different age groups etc'. The second chapter focuses on two of the largest infrastructure projects that took place in the capital during the second half of the $19^{\text {th }}$ century: the construction of the Isabel II water canal (which provided the capital with fresh water from the Lozoya river); and the expansion of the railroad system which connected the capital both to its immediate surrounding towns (via the Aranjuez line) and to the Pyrenees and the French border. These two projects were unprecedented in terms of financial investment and of the scope of manpower. They were supposed to solve several of the capital's major problems by decongesting the city-center and improving the provision of primary goods and of running water.

The infrastructural improvements, however, did not prevent the outbreaks of typhoid and of cholera during the final decade of the $19^{\text {th }}$ century. Chapters $3 \& 5$ return to those traumatic outbreaks and explore the symbolic association of disease with urban poverty. Building on the correspondence between local officials and on information derived from the local press the author examines the qualitative and quantitative leap in the provision of basic health services in the capital and the attempts to develop and culture of prevention through education. Both chapters highlight the distrust expressed by poorer populations towards the municipal authorities, a distrust which to a great extent undermined the effectiveness of quarantine and fumigation efforts, as well as of the ensuing vaccination campaigns. They also analyze some of the responses offered by rural medical traditions, practiced by recently arrived migrants, to infant mortality and to the spread of disease. 
In the introduction to his book Luis Díaz Simón wrote: "Esta dualidad de Madrid como ciudad-capital ha generado cierta confusión a la hora de aproximarse al conocimiento de su historia, ya que tradicionalmente se ha tendido a sobredimensionar el papel capitalino en detrimento del análisis de la ciudad como entidad social, económica, política y cultural con vida propia e independiente de la dimensión estatal, aunque sin duda influenciada por ella" (p. 19).

Both Santiago de Miguel Salanova and Luis Díaz Simón provide an excellent description of a changing city from a localized perspective. They analyze the interactions between the everyday lives and expectations of Madrid's inhabitants, the municipal authorities and the demands of a growing local economy. They do so by exploring several similar themes: the effects of internal migration; the construction of modern infrastructures; changing property-owning and urban-planning regimes; education and employment patterns etc'. However, both books seem to ignore to some extent the effects of major political change on the course of urban development. While urban planning regimes in Spain during the period under investigation were not determined exclusively by political change both books are missing a discussion regarding the ways in which the understanding of modernization and of urbanization was effected by the economic outlook and the social orientation of different political actors. This is especially true in the chapters which cover the years of the Primo de Rivera Dictatorship and of the Second Republic.

Furthermore, both books largely ignore the debates that engaged the Spanish planning community in relation to the future development of the capital. These debates were reflected in many of the major publications of the time such as El eco de los arquitectos, Arquitectura and AC. Documentos de actividad contemporánea. While Spain's planning community is clearly not part of the immediate focus of the two books, its members played an important role in shaping public debate regarding the desired structure of the capital; the relationship between center and periphery within its boundaries; the meaning and desired shape of local unites such as the neighborhood; and the required balance between industrial efficiency, infrastructural requirements and architectural concerns.

The third book under review in this section is an edited volume which explores the consolidation of the new middle classes in Madrid and Bilbao between the years 1900-1936. The volume emerged out of a long standing cooperation between the Madrid based group Space, Society and Culture at the Contemporary Age and a research group titled Historical Demographics and Urban History at the University of the Basque Country and is edited jointly by José María Beascoechea Gangoiti and Luis Enrique Otero Carvajal. The volume opens with a short introduction by the editors in which they define the Spanish middle classes in terms of their professional background (in relation to the liberal professions, a growing group of clerks and commercial employees the service industry, as well as certain groups of qualified laborers); their expanding leisure time and their patterns of consumption; as well as their social expectations.

The first chapter (by Luis Enrique Otero Carvajal) sets the stage for the entire volume by defining the emerging urban middle classes -alongside the growing workers' movement- as the protagonists of Spanish modernity. The chapter explores the accelerated processes of urbanization and modernization experienced by Spanish society; the changes in the structure of the Spanish labor market; and the emergence of new spaces of leisure and of consumption (in the shape of department stores, cin- 
emas and dance halls, sports clubs etc.). He then goes on to analyze the evolution of Spain's political system following the introduction of general male suffrage and the expansion of women's vote. Carvajal examines the ways in which the city of Madrid evolved in order to accommodate such changes, becoming a center not only of political and administrative life but also a home to the growing service, banking and industrial sectors with both national and international connections.

The first section of the second chapter (by Rubén Pallol Trigueros) examines the growing importance of Madrid's service industry during the first decades of the $20^{\text {th }}$ century. The second section of the chapter focuses on two practices which the author views as detrimental in defining the new middle classes: the employment of in-house help and the commitment to children's continued education. While the first practice freed some middle class women to either enter the professional world or enjoy the new leisure culture offered to them by the city, the second prioritized the socio-economic progression of middle class children over the economic gains derived from their early entry into the labor market.

The third chapter (by Manuel González Portilla, Josu Hernando Pérez and José Urrutikoetxea Lizarraga) explores the consolidation of the new Basque middle classes in relation to two different models of industrialization: the first characterizing the accelerated industrial development of the Bilbao area and the second undergone by smaller towns and cities in the Gipuzkoa region. Here too great emphasis is put on the different educational and professional paths taken by middle class families in regards to their children. However, the authors emphasize the diversity of "middle class experiences" and point to the ways in which the size of the community and the nature of the local economy affected the practices and the expectations of this evolving class.

Chapters 4, 5 \& 9 (by Santiago de Miguel Salanova, Fernando Vicente Albarrán, Arantza Pareja Alonso and Susana Serrano Abad) zoom-in on the changes which took place in the working environment of office clerks and qualified laborers in Madrid and in Bilbao. The chapters analyze the enhancement of professional training and the breaking down of office life and of industrial work into differentiated categories (each with its pay level, training requirements and working benefits). They explore the professionalization of recruitment processes and the growing incursion of work life into home life. As the authors demonstrate, the later process was shaped not only by new patterns of after-work socialization but also through the institution of new social, medical and housing benefits for employees. Such benefits aided many working populations, but also increased their dependency on their employers.

Chapters 6 \& 7 (by Borja Carballo Barral and José María Beascoechea Gangoiti) analyze urban expansion by focusing on the incipient practice of functional zoning in both Bilbao and Madrid. They trace the early stages of functional differentiation of space and demonstrate the impact of functional thinking on social segregation. They explain the ways in which functional zoning affected land prices and the perceptions of center versus periphery in the development of urban space. The authors also explore the concerns of different populations in choosing their place of residence within the city (the status of the neighborhood, the centrality of its location, existing infrastructures and educational services; its proximity to one's workplace, and the nature of the community).

Chapter 8 (by Nuria Rodríguez Martín) examines the role of middle class women as the agents of a new consumerist culture and focuses on the new forms of adver- 
tising that were employed in order to shape their tastes and influence their shopping practices. The chapter further analyzes the relationship between the growing buying power of the urban middle classes and the consolidation of modern forms of commerce.

Chapter 10 (by Nieves Basurto) focuses on the new professional publications in the fields of construction, architecture and of urban planning. The chapter traces the role of professionals in introducing new materials and construction techniques and in influencing the political and social discourse on the desired direction of urban planning; of housing policies; and of infrastructure provision. Chapter 11 (by María Jesús Pacho Fernández) focuses on the case of Bilbao and examines the ways in which functionalism and technical advancements in the field of construction facilitated the experimentation with new housing modules. It looks specifically at the emergence of housing cooperatives and low-income housing schemes all of which emphasized the need to take into consideration the needs of different households and their purchasing capacities.

The final chapter (by Pedro Novo López and Nuria Rodríguez Martín) deals with the expansion of transport, electricity and water infrastructures within the metropolitan areas of Madrid and Bilbao. The chapter examines the struggle to finance public infrastructures in a situation of constant economic hardship on the part of the municipal authorities. It explores the increased role of private capital in financing large-scale projects and the potential tensions that arose from the different agendas of those involved in defining the scope and goals of infrastructure projects.

In conclusion, this volume clearly provides a "thick description" of the process which led to the emergence of the new Spanish middle classes. Stepping beyond definitions which are encored solely in professional and economic status the volume ties the emergence of this social group to the modernization of urban space itself. It does so by pointing to the ways in which modern urban space both attracted those already defined as belonging to the middle classes and fostered new practices and expectations that further differentiated them from other social groups who inhabited the Spanish city. The comparative perspective of the volume allows the authors to contemplate urban spaces in which the relationship between modern society, culture and economy varied significantly. Different paths towards industrialization and modernization produced heterogeneous cities, which in their turn produced varied "middle class experiences". Out of this panorama emerges a description of "class" at its best: taking into account not only age and gender but also the implications of different educational and professional experiences, patterns of leisure and of consumption and specific configurations of the nuclear family. This description - tied as it is to the development of the modern city- highlights the importance of space not only as the container of social relations, but also as constantly produced by them. It highlights the fact that the story of the emergence of the modern middle classes cannot be told separately from that of the city which shaped their lives and was shaped by their actions and expectations. 